\title{
Getting the \\ Institutions Right \\ for Gender \\ Mainstreaming
}

By Diana Højlund Madsen

Strong international commitment has been expressed to gender mainstreaming in the post-Beijing eva. But what happens when the global strategy of gender mainstreaming is translated into practice at the local level? When emphasising the institutional perspectives of mainstreaming processes, the role of national gender machineries and gender desk officers become salient, in this case in the context of Ghana.

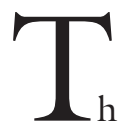

he introduction of gender mainstreaming with the Nairobi Forward-Looking Strategies in 1985, and the commitment to gender mainstreaming stressed in the Beijing Platform for Action from 1995, has been seen by development actors at national and international level as the solution to bringing gender into the centre stage or the mainstream. Gender mainstreaming was celebrated as a victory by such different actors as gender ambassadors from the women's movement and the bureaucracies in the south as well as the north. The message of gender mainstreaming has been travelling around the world and the word has been spreading from the UN conferences in 1985 and 1995. It has since then been repeated in numerous Gender-And-Development fora with gender ambassadors as the messengers from different institutional settings. Gender mainstreaming has (ironically) been labelled as 'UNesque feminism' (Manicom 2001: 13) reflecting its global origin and association 
with the high-level UN conferences. More recently the importance of gender mainstreaming and gender equality has been further stressed at a policy level with the Beijing +15 conference and the formulation of empowerment of women and gender equality as one of the Millennium Development Goals to be achieved by 2015 .

In this article I look into how the international commitment to gender mainstreaming has been translated into practice in a specific local context, namely Ghana. ${ }^{1}$ This commitment is reflected at the local level in the setting up of a gender mainstreaming apparatus: a national gender machinery with the overall mandate to mainstream it, the Ministry of Women's and Children's Affairs (MOWAC), has been established and mainstreaming is stressed in the Ghanaian National Policy on Gender and Children from 2004, followed by a Strategic Implementation Plan 2005-2008. In addition, gender desk officers (GDOs) should be established in the sector ministries. I argue that despite its global character, the gender mainstreaming talk needs to be studied in a specific local context. Furthermore, I discuss why gender mainstreaming seems to have failed to deliver on its promise to transform gender relations. The main argument is that the Ghanaian version of gender mainstreaming is limited in width and scope to an integrationist version of gender mainstreaming, but even in this version it has not been effective due to the weak institutional framework. 'Getting the institutions right' is imperative for the success of mainstreaming. ${ }^{2}$ Although the gender language has shifted from WomenIn-Development (WID) to Gender-AndDevelopment (GAD) and gender mainstreaming, 'getting the institutions right' remains a challenge. Here I argue that there is a need to (re)focus on the institutional perspectives of gender mainstreaming which are shaping the actual processes of adopting and adjusting gender mainstreaming at a local level.
In my work I am inspired by existing research on gender mainstreaming and institutional development. Some researchers apply a discursive perspective, which is important to unfold the concept of gender mainstreaming (for example Bacchi 2010; Manicom 2001: Poulsen 2006). Others, like Goetz (1995), focus on the institutional perspectives but without dealing with gender mainstreaming to a very large extent. However, Jahan (2005) and Rai (2007) are examples of researchers who include the institutional perspectives in their work on gender mainstreaming. Inspired by the these, I claim that 'bringing back in' the institutional perspectives in analyses of gender mainstreaming provides important insights on the apparent lack of mainstreaming results and helps us move beyond gender rhetoric. First, these perspectives provide an insight into the actual processes of mainstreaming at the state level in a specific context. Second, they illustrate the importance of establishing alliances at the level of the state bureaucracy, inside as well as outside.

The need to focus on the institutional perspectives, including the analysis of the actors of gender mainstreaming institutions at the state level, is emphasised by the gender mainstreaming critique put forward by representatives of the Ghanaian women's movement. ${ }^{3}$ The enthusiasm which marked the Beijing era seems to have been replaced by a sceptical approach to the way in which gender mainstreaming has been framed. The first point of critique of the Ghanaian women's movement is that gender mainstreaming has become a business for the state (only) implying a focus on 'women in the state' in the form of the GDOs instead of bringing about a transformation of the institutions. As a consequence gender mainstreaming is somewhat detached from women's lives at the grassroot level. Their second point of critique is that gender mainstreaming has lead to depolitisation of women's issues and gender. It has become 
a technical exercise which does not address the inequalities at play and therefore downplays the power struggles implied. Their third point of critique is that gender mainstreaming has taken focus away from women's empowerment. As a consequence voices within the women's movement advocate for a (re)focusing on women's empowerment.

The article is based on data from my fieldwork in Ghana from September 2007 to March 2008. The main sources of information are interviews ${ }^{4}$ carried out at the state level with four representatives from the national gender machinery and eleven GDOs. The latter represent the total sample of GDOs in place at the time of the fieldwork. Furthermore, I refer to tendencies from interviews carried out with eleven representatives from the women's movement. The data collection also included nine observations in different Ghanaian gender fora and analyses of (gender) policy documents from the state level. 5 The Ghanaian case has been selected because of the establishment of an institutional framework for gender mainstreaming (MOWAC and GDOs), and its potential for unfolding interesting perspectives on the relations between the state level and the women's movement. ${ }^{6}$

The article is structured in three parts. First, I present different approaches to gender mainstreaming and define institutionalisation, including the introduction of some critical elements for the functioning of gender mainstreaming institutions. Then, I turn to the Ghanaian setting and analyse the national women's / gender machinery and the mainstreaming initiative regarding the establishment of GDOs. Finally, I end the article with some concluding comments.

\section{GENDER MAINSTREAMING AND} INSTITUTIONAL DEVELOPMENT:

\section{A THEORETICAL OUTLINE}

Gender mainstreaming is a strategy to promote another goal, namely gender equality, and as such it is not an end in itself. Furthermore, mainstreaming should be understood as a process taking gender out of its isolated position and making it part of mainstream policies to be dealt with in all areas, at all stages and by all actors. ${ }^{7}$ The debate on gender mainstreaming is polarised between two approaches; an 'agenda-setting' approach and an 'integrationist' approach (see Jahan 1995). Below I relate these approaches to respectively an optimist and a pessimist view on mainstreaming.

In the optimist view on gender mainstreaming the emphasis is on the transformative potential of the strategy with its emphasis on gender and institutional development. The focus here is on taking the development of gender mainstreaming further as it (yet) needs to unfold its full potential. The optimism is based on the 'agenda-setting' approach aiming at taking gender mainstreaming in a more democratic-participatory direction.

The idea behind the 'agenda-setting' approach implies a gendered transformation of the development agenda and of the institutional framework with the thinking of Goetz (1995) in mind. The participation of women or the women's movement in decision-making processes is seen as fundamental for bringing about change and reorienting existing priorities (i.e. the mainstream). Here the idea is that women's agenda should become recognised in mainstreaming policies (Jahan 1995). Others (Verloo 2007) stress that women's voices should be included through consultative processes as mainstreaming processes should also be about empowerment and ensuring political space for other actors like the women's movement.

In opposition to this, the pessimist view on gender mainstreaming emphasises a 
number of negative developments which gender mainstreaming should be blamed for. This regards for example depolitisizing 'women's issues' and 'gender', closing down of specific units dealing with women's issues and gender and the related invisibility of these issues. The pessimism is based on the 'integrationist' approach to gender mainstreaming as pessimists believe that the development rather takes mainstreaming in a technical-bureaucratic direction with a focus on so-called neutral policymaking at the state level.

The 'integrationist' approach implies building gender into the existing institutional framework and development agenda, thereby securing incremental gains, but with no transformation as a result. The strategy informing this approach is one of widening women's issues and gender to a broader spectrum of sectors or to integrate them into as many sectors as possible. In line with this, gender mainstreaming is seen as merely an 'institutional device' (Arnfred 2003: 81) and 'agenda-setting' is considered to have very little to do with the actual realities. The only form of agenda-setting taking place is the one undertaken by state actors, not by the women's movement (Arnfred 2003).

Gender mainstreaming and institutionalisation are closely interlinked as it is the aim of mainstreaming to create permanent change and make gender a part of institution's everyday work. A source of inspiration for understanding the implications of focusing on processes of institutionalisation is the work of Levy (1996). She defines institutionalisation as follows:

The processes whereby social practices become sufficiently regular and continuous to be described as an institution, that is social practices that are regularly and continuously repeated, are sanctioned and maintained by social norms and have a major significance in the social structure (Levy 1996: 1).
However, gender mainstreaming is not only regulated by international and national norms but also by laws. In her work Levy (1996) establishes a web of institutionalisation where she puts together the different elements of the web to ensure institutionalisation of gender, but without identifying who should be the 'spider' weaving the web, and how we should move from one step to the next. My concern is mostly with the first question which also gives an idea of the preconditions for gender mainstreaming. Some of the elements are similar to those identified by Rai (2007) who has been another source of inspiration to me.

Rai (2007) identifies some critical elements for the working of national machineries. The first critical element is the question of its location, implying that the national machinery should be based at the highest level possible and have the authority to influence government policy. In practice this includes the form of the machinery as well as the policy area to which the women's/gender machinery is related. The second critical element is the mandate and functional responsibility which should be clearly defined and delimited in order for it to live up to the (often) very high expectations and deliver results. The third critical element is the buman and economic resources accessible for undertaking the work, including the number of staff as well as their exposure to gender and gender mainstreaming. Included in this are also the economic resources available for their work from the government budget and from foreign donors since national machineries in an African context are often dependent on foreign aid. The fourth critical element is the links with the women's movement which, on the one hand, should represent the voices of the 'Ghanaian women' and ensure that they are heard. On the other hand, these links have a role to play in holding the national machinery and government accountable in terms of gender mainstreaming. 8 
The work of Rai (2007) should be understood as a part of a debate, even within the UN, on whether state-based women's or gender machineries in their present form are in a position to promote mainstreaming and gender equality. From Rai's perspective the national machineries are able to promote women's/gender interests but only under certain conditions related to the critical elements described above.

The national machineries are established on the basis of a UN resolution urging signatory states to establish such machineries at the beginning of the UN decade. 9 These machineries can take the form of an independent ministry, like in the Ghanaian case, a department, like the Danish case, a commission or a committee. The role of the national machineries is defined by Rai with reference to the Beijing Platform for Action as "...central policy coordinating units inside the government. [Their] main task is to support government-wide mainstreaming of a gender equality perspective in all policy areas. National machineries are thus 'catalyst' for promoting gender equality and justice" (Rai 2007: 17).

However, this definition is rather limited and formalistic as it is also important to include their role in promoting state feminism (Gouws 2005) and thereby ensuring the mobilisation of all gender mainstreaming actors and institutions. According to Gouws (2005) the national machineries aim at influencing policy-making through women in the state or femocrats, ${ }^{10}$ on the one hand, and through the women's movements and their constituency, which legitimised the establishment of the machineries in the first place, on the other.

The Ghanaian institutional set-up plays a role in putting gender mainstreaming talk into practice. Therefore, it is important to explore further to what extent it has been enabling for gender mainstreaming. Thus, in the following section I turn to the Ghanaian context.

\section{The Ghanaian Machinery as}

\section{a Champion of GENDER} MAINSTREAMING?

The criteria developed by Rai (2007) are also of relevance in the Ghanaian context. However, the national gender machinery scores low on most of the criteria. The Ghanaian national machinery has a historical record of instability with shifting locations at the expense of capacity-building within the machinery and a marginalised physical location.

The optimism that characterised the 1970s when the national machineries for the advancement of women were established in many African countries has long since evaporated...Lack of consistent and clear government support, a general lack and instability of human and material resources, dependence on donors and lack of credibility with civil society institutions (Tsikata 2001: 1-2). ${ }^{11}$

The quotation above is from a NGO evaluation of the national machineries carried out by Third World Network ${ }^{12}$ in eight African countries, including Ghana. Some of the conclusions are still of relevance today. In 2001 the new Ministry of Women's and Children's Affairs (MOWAC) was established by president Kufour from the $\mathrm{NPP}^{13}$ party replacing the National Council on Women and Development from 1975 (the year of the beginning of the UN decade). At first glance this indicates a strengthening of the institutional set-up and an increased commitment to mainstreaming efforts. However, a closer look unveils that in practice the new national machinery is left with few possibilities of facilitating mainstreaming processes as its work is hampered by a number of factors related to the critical elements identified above.

Firstly, with the establishment of MOWAC the machinery is located at a high level as a ministry in its own right and with cabinet status based at the central ministeri- 
al area of Accra. But one may question if the attachment of 'women' and 'gender' to other issues like 'children's issues' provides the best point of departure for mainstreaming compared with, for example, the areas of planning and finance. Putting together women and children underlines the responsibility of women (only) for the children and emphasises their role as mothers (only). From a more positive perspective, however, it may also ensure the addressing of issues related to women in this capacity such as, for example, maternal mortality.

Secondly, the ministry has an all-inclusive mandate and functional responsibility taking upon itself such different roles as doing advocacy in relation to gender mainstreaming at the state level and being expected to provide technical assistance for other ministries, monitoring (as the Minister is represented at cabinet level she can oversee policies and programmes but she is not granted right to do so), and implementing since the ministry itself carries out projects on women's economic empowerment (see also Goetz 2007).

Thirdly, the problems of a broad mandate should be seen in the light of the fact that MOWAC is seriously suffering from underfunding and understaffing. This is underlined by the ministry itself in a presentation folder. Concerning the economic resources a large share has been allocated to the establishment of the ministry in its early years but in the later years the figures from MOWAC illustrate that the budget estimate is lower than the needs assessment, and that the actual use of resources for services is lower than the budgeted amounts. All in all this indicates a situation of underfunding but also a national machinery that has (paradoxically) not been able to spend the resources allocated due to understaffing.

The buman resources relates both to the number of staff as well as their background. During the time of my fieldwork, one third of the planned positions were not occu- pied. Furthermore, only a few staff members have gender mainstreaming skills. In the interview material one particular pattern becomes clear, namely that a number of key persons working with gender at the state level (i.e. the femocrats) have become disillusioned. The following quotation exemplifies this:

"If also in terms of people's aspirations, you know this is an organisation that is supposed to be showing that gender is mainstreamed. Then you come and you do not think that if your aspirations are to help to further gender mainstreaming in the country, so you come and work for an organisation which is supposed to do that and you do not see that happening, you just decide to go to another ministry" (MOWAC, 09.01.08).

To sum up, despite its elevated status, the Ghanaian machinery leaves quite a lot to be desired according to the criteria developed by Rai. The femocrats in the national gender machinery seem to be fighting an uphill battle within the institutional framework. The functioning of the national machineries and their ability to promote gender mainstreaming vary due to their dependency on individual femocrats and the degree of an 'enabling' institutional environment.

Although, the national machineries play a role in mainstreaming, they cannot do it alone. By definition making gender part of the mainstream involves other actors and institutions. In the Ghanaian context other gender mainstreaming actors are the GDOs in the sector ministries within the state bureaucracy which may potentially act as 'innovators' of gender mainstreaming. In the following I analyse the role of these GDOs.

\section{The National Gender Mainstreaming Initiative}

The notion of 'innovators' in the bureaucracy refers to the work of Staudt and Lotherington dealing with different types 
of bureaucratic responses to the agenda of 'women' and 'gender'. They define 'innovators' as: “supporters of WID policy, [who] are mainly women...located at all levels [with the] majority at middle and lower professional levels, but with an increasing number of men joining. They have been active in putting gender-responsive technical cooperation policy on the agenda and keeping it there" (Staudt 1998: 68-69, with a reference to Lotherington 1991: 73-77). Staudt and Lotherington also mention other categories of bureaucrats like 'loyal bureaucrats', 'hesitators' and 'hard-liners'. ${ }^{14}$ Although, their focus is on WID instead of GAD and gender mainstreaming some of their reflections are useful here to reflect on the bureaucracy as more diverse, fragmented and potentially reflecting different positions on 'women' and 'gender'.

In the following I will use interview examples to illustrate patterns and differences among Ghanaian GDOs in terms of their possibilities of acting as 'innovators'. With the establishment of MOWAC in 2001 the role of the GDOs as spearheads of national gender mainstreaming efforts was emphasised. ${ }^{15}$ The national machinery is facing the challenge of promoting the rather difficult agenda of gender mainstreaming over which it has relatively little or no control. In the national mainstreaming exercise GDOs are seen as potential allies who can assist in penetrating the sometimes hostile ministerial environments. With the criteria developed by Rai in mind I analyse to what extent the GDOs have been able to act as mainstreaming 'innovators'.

First, concerning the location of the GDOs, one could rather speak of non-location as they were, for different reasons, not in place in half of the ministries. ${ }^{16}$ Of the other half that were in place only a handful were in senior positions and based in the unit dealing with policy development. The following two quotations illustrate this problem:
"When new policies are made - how involved are we [as GDOs]...I would not say we were even involved... Because I think with the GDO issue that directors should have been appointed for that position because directors are part of decision making, I am not part of it... But the thing is, you ask a director to be the GDO and they do not take it as a serious issue. There was a time a workshop was organised for directors and even chief directors - the chief directors to sit in a workshop for gender mainstreaming will you believe it? They did not attend it” (GDO, 07.01.08).

"Firstly, our chief director is interested in this whole gender issue. Secondly, I find myself as a [part of the Policy, Planning, Monitoring and Evaluation Unit] and I know the programmes of the ministry and the agencies, I am in charge of the writing of reports as well as the monitoring, so I am quickly able to monitor what is going on and when you submit your budget... But what about the others? I can tell you that some of the gender desk officers - even secretaries can be appointed as GDOs, because the person who was supposed to be coming was not coming and because they presume it is for women's affairs there was a secretary appointed to attend a meeting. This secretary does not attend senior officers meetings, so how can she carry the message across?"(GDO, 04.12.07).

Secondly, in terms of mandate and functional responsibility the position as a GDO is an added-on task with more or less time allocated, but not a full-time position. This also means that it can be subtracted again (Longwe 1997), which has actually happened in the Ghanaian case within some ministries. In all cases, the appointment of the GDO is a top-down process where the GDO has had no influence on the appointment. However, it can be assumed that some of the GDOs have been appointed to the position because of their practical background in gender work and/or their degree within a similar field. Furthermore, there is no common framework or job de- 
scription in place, which leaves it to the GDOs themselves to define their role:

"The procedure I can not tell you, because I was on leave at that time and when I resumed, I was just asked to handle gender, I did not know what went on, it was just the minister who said that I should handle gender...but it did not seem like there was anything concrete, you know like a GDO this is your duty, so then I think the perception was that gender is about women, so a woman should handle this" (GDO, 04.12.07).

Thirdly, the question of resources is crucial for the GDOs. Most of them do not have specific resources for their work. However, it seems that a duplication of the efforts initiated by MOWAC to increase the pool of economic resources available is taking place at the level of GDOs. This is reflected in the attempts of the GDOs to budget for gender within their respective ministries in line with similar processes of the new initiative of gender budgeting at the national level. ${ }^{17}$ Two GDOs report about their attempts to obtain economic resources for their work:

"Men constitute the planning group and most of the time they do not see gender as any serious issue. What about these women - what do they want (?) They will just leave you out... if you are not there, they are not opening it up - people do not see gender issues as an issue that is a priority to them, they think that other issues are more pressing... But it will change, because now I have done a lot of lobbying with my boss, at that time I was just new and there was no time for me to go there and tell them what it was all about, so they wanted to push me out and before I could convince them to bring me on board, they were already finished with the plan" (GDO, 24.01.08).

"I took my leave, because I am very, very tired. rou do not go on leave, you just work 24 hours. I was part of the initial process, I gave my in- put, but I did not sit in all the way through... But I know I made some inputs - our division the Policy, Planning, Monitoring and Evaluation unit we sit down together and draw our budget and I made sure that gender concerns were captured... For the first time some money has been put down for the gender office... So I am proud!" (GDO, 15.01.08).

These two GDOs have both strived to attract economic resources for their work, with the latter being more successful than the first. The first example also gives an indication of the resistance within the bureaucracy. However, her strategy has been to navigate within the ministerial framework and prepare the ground by lobbying her superior to achieve goodwill and make him address the issue of gender at meetings for Directors and thereby become included in the planning process the following year. Another GDO was more successful as she managed to get her own budget for gender training in her ministry. The allocation of resources for a certain position (like the GDO) and agenda (like gender mainstreaming) in itself contributes to the recognition of their position and agenda.

Concerning the human resources, the GDOs in place are often the only ones to focus on gender issues and gender mainstreaming within their ministry, at least when they are first appointed. However, some of the GDOs include other ministerial staff members in their work to the widest extent possible, for example by bringing along staff members to gender activities:

"It is like you are the GDO, so it is like if anything comes up, if there is a programme somewhere on gender it is you, if there is something that needs to be done on gender then it is you one person it is not easy, but I have told them that at least you get one or two persons in addition to me to make it about three, so it gets one man, one wo-man... So sometimes when I am going for a meeting, I take one of my subordinates with me - those are the people I can pull 
along... Or I take the men along...” (GDO, 04.12.07).

\section{"My big challenge is getting this abuse in their} minds of women coming to take over. I am strongly advocating to get a male to give it a balance... it is for males and females, so I would strongly advocate for a male person to get them to see that you can work hand in hand" (GDO, 15.01.08).

The GDOs involved in activities on gender and gender mainstreaming try to include other staff members to ensure a wider base of support for their activities and eliminate potential resistance through the establishment of alliances with their fellow male colleagues. Furthermore, some of the GDOs are trying to expand their gender activities further by referring to a 'gender office', although only one person (the GDO herself) is allocated for the work. Another GDO has plans of establishing a 'gender centre' attached to her office where other ministerial staff members will find information on gender. These attempts can be interpreted as an initial stage in a process of institutionalisation.

Summing up only a handful has been able to act as 'innovators'. The GDOs are striving for recognition of their position within the bureaucracy including being visible and being taken seriously. According to the criteria set up by Rai, the framework within which the GDOs operate are hampering their possibilities. However, key individuals try to manoeuvre within the existing framework (see also Moser 2005). Successful gender mainstreaming has relied too much on individual capacity and personality rather than being institutionalised in a way that transcends the individuals assigned to carry out gender mainstreaming.

\section{CONCLUSION}

The Ghanaian case seems to be more in line with the pessimist view on gender mainstreaming: The women's movement does not play the role in gender mainstreaming prescribed by the 'agenda-setters'. The gender mainstreaming project offered is simply not very attractive to them. Rather, the adopted approach seems to have more to do with the 'integrationist' perspective and inclusion of women at the state level. However, even this more limited approach has not been very effective due to the weak institutional framework.

Gender mainstreaming is not an 'institutional device' as referred to by the pessimists. Rather it can be considered a rhetorical device. Paradoxically, gender mainstreaming institutions themselves are not very well institutionalised as demonstrated in the analysis of the Ghanaian national machinery and the GDOs. The success of gender mainstreaming is strongly dependant on individual women at the state level (femocrats) moving the processes forward. As a consequence, mainstreaming processes are vulnerable to changes and run the risk of collapsing with the change of staff. Furthermore, it is questionable if everybody within the bureaucracy is suitable to deal with mainstreaming or act as 'innovators'.

\section{Notes}

1. This article is based on my $\mathrm{PhD}$ dissertation entitled Getting the Institutions Right for Gender Mainstreaming - the Strategy of Gender Mainstreaming Revisited in a Ghanaian Context, Roskilde University 2010.

2. The title of the article is a re-formulation of the title of the work by Goetz Getting the Institutions Right for Women in Development from 1995. I have decided to paraphrase part of this title to illustrate that 'getting the institutions right' for gender mainstreaming is not (only) a mantra of the past but an urgent part of the present.

3 . The role of the Ghanaian women's movement and their critique of gender mainstreaming have been analysed in depth in my dissertation.

4. Altogether I carried out forty-four interviews including eighteen interviews with donor repre- 
sentatives from the Danish International Development Agency (DANIDA). The latter are not dealt with in this article.

5. The National Gender Policy (2004), the Strategic Implementation Plan (2005), a pamphlet about MOWAC (2007) and documents on the MOWAC budget (2007).

6 . Furthermore, the Ghanaian case was selected because the country receives a large amount of development aid from DANIDA. The perspective of gender mainstreaming in donor programmes represented by DANIDA is also included as part of the research. However, that perspective is not part of this article.

7. The official definition of the UN Economic and Social Council from 1997 is: "Mainstreaming a gender perspective is the process of assessing the implications for women and men of any planned action, including legislation, policies or programmes, in all areas and at all levels. It is a strategy for making women's as well as men's concerns and experiences an integral dimension of the design, implementation, monitoring and evaluation of policies and programmes in all political, economic and societal spheres so that women and men benefit equally and inequality is not perpetuated. The ultimate goal is to achieve gender equality." 8. This is dealt with in-depth in my dissertation, but I refer to the gender mainstreaming critique set forward by the women's movement in the introduction to this article.

9. In 1991 nearly all African countries had set up national gender machineries and by 2006 thirty-six of them had ministries for women/gender (Tripp 2009).

10. The term femocrat was originally defined by Sawer (1998) and refers to feminist bureaucrats promoting a feminist agenda from within.

11. Dzodzi Tsikata is a Ghanaian gender researcher and activist.

12. Third World network is an international network of groups and individuals who seek greater articulation of the needs and rights of the people of the third world. The network has an office in Accra, Ghana.

13. The New Patriotic Party gained power in 2000 and followed Rawlings and the National Democratic Congress (NDC) which had been in power since 1981. The NDC was critical of the establishment of a separate ministry, but after they regained power in 2008, MOWAC remained in place.

14. Since I have not interviewed other state representatives than the ones from the national gender machinery and the GDOs, I will not go into details with the other categories.
15. As a follow up of the 1995 Beijing Platform for Action an initiative was embarked upon to establish GDOs in all ministries and other state institutions (initially women's desks). Even in 1995 their role as potential gender mainstreaming innovators was mentioned, but since 2001 it has been emphasised to a much larger extent.

16. Reasons mentioned were the novelty of certain ministries, that the minister herself is a woman (and therefore the ministry would be sensitive to women's and gender issues; in this particular case the female minister in question has been dealing with these issues before), that it is not seen as their concern and that they lack resources. Furthermore, the follow-up on the initiative only related to some of the ministries.

17. The gender budgeting initiative was approved in December 2007. However, it was not possible to collect any data on this as almost no data were available at the end of my fieldwork in February 2008.

\section{LITERATURE}

- Arnfred, Signe (2003): Questions of Power Women's Movements, Feminist Theory and Development Aid, in: Discussing Women's Empowerment - Theory and Practice, SIDA-Studies 3. - AWID (2004): Gender Mainstreaming: Can It Work for Women's Rights?, in Spotlight 3.

- Bacchi, Carol Lee (2006): Approaches to Gender Mainstreaming - What's the Problem Represented to Be?, in: Medien es Zeit 4.

- Bacchi, Carol Lee (2008): Gender Mainstreaming or Diversity Mainstreaming? The Politics of

"Doing", unpublished draft.

- Bacchi, Carol Lee and Eveline, Joan (2003):

Mainstreaming and Neoliberalism: A Contested

Relationship, in: Policy \& Society 22(2).

. Goetz, Anne Marie (1995): Getting the Institutions Right for Women in Development, in: IDS Bulletin 26(3).

- Gouws, Amanda (1996): The Rise of the Femocrat?, in: Agenda 30.

- Goetz, Anne Marie (1998): Mainstreaming Gender Equity to National Development Planning, in: Caroline Miller \& Shahra Razavi (eds.): Missionaries and Mandarins - Feminist Engagement with Development Institutions. UNRISD, London. - Gouws, Amanda (2005): (Un)thinking Citizenship: Feminist Debates in Contemporary South Africa. Ashgate, England. . Goetz, Anne Marie (2007): National Women's 
Machinery: State-based Institutions to Advocate for Gender Equality, in: Shirin M. Rai (ed.): Mainstreaming Gender, Democratizing the State?. Manchester University Press, Manchester.

- Jahan, Rounaq (1995): The Elusive AgendaMainstreaming Women in Development. Zed Books, London.

- Levy, Caren (1996): The Process of Institutionalising Gender in Policy and Planning: The Web of Institutionalisation. Development Planning Unit, University College London.

- Longwe, Sara Hlupekile (1997): The Evaporation of Gender Policies in: the Patriarchal Cooking Pot, in Development in Practice 7(2).

- Lotherington, Ann Therese et al. (1991): Implementation of Women-In-Development (WID) Policy). Norut Samfunnsforskning, Norge.

- Madsen Højlund, Diana (2010): Getting the Institutions Right for Gender Mainstreaming - the Strategy of Gender Mainstreaming Revisited in a Ghanaian Context, $\mathrm{PhD}$ dissertation, Roskilde University, Roskilde.

- Manicom, Linzi (2001): Globalising Gender in or as - Governance? Questioning the Terms of Local Translations, in: Agenda 48.

- Mensah-Kutin, Rose et al. (2000): The National Machinery for Women in Ghana: An NGO Evaluation, National Machineries Series 3, Third World Network-Africa.

- Miller, Caroline \& Razavi, Shahra (1998): Missionaries and Mandarins - Feminist Engagement with Development Institutions. UNRISD, London. - Ministry of Women's and Children's Affairs (2004): National Policy on Gender and Children, Accra.

- Ministry of Women's and Children's Affairs (2005): Strategic Implementation Plan (20052008), Accra.

- Ministry of Women's and Children's Affairs (2007): Brief on MOWAC Budget to parliamentary Committee on Gender and Children. Accra.

- Ministry of Women's and Children's Affairs (2007): Gender Equality and Women's Empowerment in Ghana, Accra.

- Poulsen, Helle (2006): The Elusive Gender - The International Labour Organisation and the Construction of Gender Equality, PhD dissertation, University of Copenhagen, Copenhagen.

- Rai, Shirin M. (2007): Mainstreaming Gender, Democratizing the State? Manchester University Press, Manchester.

- Sawer, Marian (1998): Femocrats and Ecorats:
Women's Policy machinery in Australia, Canada and New Zealand, in: Caroline Miller \& Shahra Razavi (eds.): Missionaries and Mandarins - Feminist Engagement with Development Institutions. UNRISD, London.

- Tsikata, Dzodzi (1997): Gender Equality and the State in Ghana: Some Issues of Policy and Practice, in: Engendering African Social Sciences, CODESRIA Book Series.

- Tsikata, Dzodzi (2001): National Machineries for the Advancement of Women in Africa: Are They Transforming Gender Relations?, report from Third World Network-Africa.

- Verloo, Mieke (2001): Another Velvet Revolution? Gender Mainstreaming and the Politics of Implementation, IWM Working paper 5, Vienna.

- Verloo, Mieke (2005): Displacement and Empowerment: Reflections on the Concept and Practice of the Council of Europe Approach to Gender Mainstreaming and Gender Equality, in: Social Politics 12(3).

- Verloo, Mieke (2007): Multiple Meanings of Gender Equality - A Critical Frame Analysis of Gender Policies in Europe. CEU Press, Budapest.

\section{SUMMARY}

Getting the Institutions Right for Gender Mainstreamning

The article focuses on processes of translating the global strategy of gender mainstreaming into practice at the local, Ghanaian level. Analysing mainstreaming from an institutional perspective, the roles of the national gender machinery and the gender desk officers in sector ministries are scrutinised according to critical elements for their functioning. The main finding suggests that successful mainstreaming processes to a large extent depend on individual women at the state level (femocrats) as a consequence of a low level of institutionalisation of the strategy.

Diana Højlund Madsen

$\mathrm{PhD}$, cand.scient.soc

Roskilde University 